\title{
Indian indenture History and historiography in a nutshell
}

\author{
Brij V. Lal \\ Brij Lal is professor emeritus, School of Culture, History and \\ Language, ANU College of Asia and the Pacific
}

\section{ABSTRACT}

The establishment of the academic study of Indentureship is a relatively recent development that has been led by descendants of indentured labourers from across the diaspora. This article highlights key moments in both the history and historiography of Indentureship. Looking first at the system established by the British on plantations across their colonies, it goes on to consider the variety of labourers' backgrounds and the process of social equalisation that was fostered by both voyage and plantation. Considering the injustices of the system, the author emphasises the ways in which labourers were able to disrupt the power of the plantocracy and analyses the particular perils the system held for women. The religious life of the labourers as well as the maintenance of the Panchayat and the importance of the Ramayana are also weighed. The historiography section of this article traces the attention paid to the system of indenture and the diaspora it created; from the initial attentions of missionaries and 'benevolent' organisations in the nineteenth century to the creation of a global network of scholars of Indentureship with roots in South Africa, Fiji, Mauritius, Guyana and Trinidad. It further emphasises key moments and publications during this period.

\section{KEYWORDS}

Indian indenture, Jahaji Bhai, Kangani system, caste in indenture, Hinduism in indenture, Islam in indenture, infant mortality under indenture, women under indenture, Ramayana, Panchayat, indenture abolition, Girmi 
Demerara, Chini Tapu, Sriram Desh, Fizi Tapu, Miritch Dwip, Natal. These are now-forgotten names of distant tropical 'King Sugar' colonies in the Atlantic, Pacific and Indian Oceans to which 1.3 million Indian indentured labourers went between 1834, after slavery was abolished in the British Empire, and 1917 when Indian indentured emigration ended. ${ }^{1}$ They had gone on an agreement, or Girmit, for a specified period of time after which they could return to India at their own expense after five years or at government expense after ten. But inertia, memories of a long traumatic sea voyage, concern about an unwelcome reception at home and the promise of land grants and other incentives by the colonial governments discouraged the thought of returning. In the end, only about 21 per cent did. The rest remained in their new homelands to start life anew. In time, their labour would lay the foundations of new societies and economies, from Suriname to South Africa and many places in between. Their descendants now scattered around the globe form a distinct part of the larger mosaic of a visibly growing community of the Indian diaspora.

\section{ORIGINS AND BACKGROUND}

India was chosen as a major source of labour supply because it was already a part of the British Empire and because of the belief that it was a subcontinent teeming with millions who would benefit from emigration. The various imperial powers reserved labour for their own network of colonies and Indian labour was exported to other parts of the British Empire. In this way, for example, no Indian went to Hawaii, a major sugar-producing area but under the informal control of the United States for much of the nineteenth century. Small numbers of Indian indentured labourers went to French colonies (Reunion, Guadeloupe) and Dutch territories (Suriname).

The Indian indentured labourers came from a wide range of regional and social backgrounds in India (Lal 1983). Most came from the impoverished, migration-prone districts of the north, in the earlier years from the tribal and settled plains of Bihar and later from 
the eastern districts of the United Provinces, now Uttar Pradesh. In the South, they came from the Madras Presidency (Tamil Nadu, Andhra Pradesh) and large numbers of migrants went to Mauritius and Natal, and under the 'Kangani' system to Ceylon, Malaya and Burma. Everywhere, distress in one form or another was their constant companion: distress due to droughts, crop failures, excessive revenue demands by provincial governments, fragmentation of landholdings and human exploitation. As a result, people were already on the move in search of employment in places like Calcutta jute mills, Assam Tea Gardens, Bihar coal mines and even as far away as Bombay. It was from this uprooted mass of humanity in search of a better livelihood that most of the indentured migrants came. No doubt many were fraudulently enticed into the recruiters' nets as well, promised milk and honey in the colonies. Trickery certainly was a part and parcel of the trade, but this should be seen against the backdrop of the circumstances which were pushing people off the land.

\section{FRAGMENTATION AND RECONSTITUTION}

Indenture was a complex and contested experience, a site of both fragmentation and reconstitution, of liberation and disempowerment. Many men and women perished in the process, but most survived the ordeal to build a new life for themselves. Many practices and institutions of traditional India did not survive the crossing, including the caste and joint family systems (see among others Gillion 1962). Indentured labourers were recruited as individuals, not as members of family or community or caste groups. So, the collective memory upon which people could draw was limited, partial and fragmented. And on the plantations, they were rewarded individually on the basis of work they accomplished, not on their social or ritual status. Individual initiative and enterprise mattered above all else. The caste system suffered jolts along the way. In the up-country recruitment depots, people of all castes and backgrounds were collectively 
housed in rudimentary structures or perhaps at the home of some person, all eating food cooked from the same pot. In the central depots in Calcutta and Madras, while awaiting shipment, the system was shaken further. On the long, unaccustomed ship voyages across the kala pani, the confined cabins broke down further barriers as the realisation dawned on them that, irrespective of the differences in their social and cultural backgrounds, they were bound by the same fate, fellow 'coolies' all. The plantation was, of course, the greatest leveller of hierarchy and distinction.

\section{WORK AND LIFE}

Work and life on the plantations varied between places of employment and over time, and even within places of employment. But the constant toil was hard even for a people used to the demanding routine of relentless work in their ancestral country. Complaints against employers across all the colonies included the unrelenting pace of work under harsh discipline, frequent breaches of the labour ordinances, violence and sexual assaults on women by European overseers and Indian men, unequal application of the laws and the judicial prejudice in favour of written as opposed to oral evidence. Violence was endemic in the system, though perhaps not as pervasive as folklore suggests. Indentured labourers may have been simple people from simple backgrounds, but they were not simpletons. They used a multitude of work practices to frustrate unfair demands made upon them. They struck when things got out of hand. And a sharpened cane knife (effectively a cutlass) in the hands of an enraged man was a powerful deterrent to excessive force. It should also be remembered that the planters' desire to extract maximum labour from those under their charge was informed by the need to have a healthy and cooperative rather than an unhealthy and truculent workforce. The plantation was above all else an economic enterprise.

Most important of all, indenture did not last forever. It was a longterm sentence in some places, in others a limited detention of five or 
at most ten years after which the freed labourers could begin new lives on leased or government land. It was the hope of freedom that sustained many in their darkest hours. This truth informed their approach to life and work on the plantations. Agriculture formed the centre of their lives, as petty cultivators, market gardeners or hired labourers. Some, over time, moved into small-scale trading and familyrun businesses, but for the majority agriculture remained the mainstay of their daily lives. In a strange irony, sugar cane, the slave crop, for which Indian indentured labourers were brought to work in the first place, has now either been abandoned altogether or is visibly declining due to the vagaries of world market. ${ }^{2}$ Big sugar-cane-growing companies such as the Colonial Sugar Refinery in Fiji or the Bookers in Guyana are now of blessed memory.

\section{GENDER}

An important contributor to the levelling trends on the plantations was the paucity of women in the indentured population. The Indian Emigration Act (1881) provided for the migration of 40 women to every 100 men on each shipment, increasing the number from the previous 33. This reform was a direct response to the need to create a more stable family life in the colonies and, as a bonus, a settled pool of labour supply, thus obviating the need to pay for return passages of migrants. The planters cavilled, but the Government of India refused to budge. The disparity in sex ratio meant that cross-caste and even cross-religious marriages took place everywhere, further blurring distinctions regarded as sacrosanct in India. These mixed marriages might have been another reason discouraging return to India. In time, what was an 'abnormal' response to an 'abnormal' circumstance became a normal occurrence on the plantations. ${ }^{3}$ A dozen and more scholars (Rhoda Reddock, Patricia Mohammed, Verene Shepherd, Alissa Trotz, to name a random four from the Caribbean alone) have shown how women bore the burden of racism of the overseers and sexism of their own men. Very often, they were held 
responsible for 'sexual jealousy' among men, which led to murders and suicides. ${ }^{4}$ Accused of lacking the 'motherly instinct', they were blamed for the excessive infant mortality rates on the plantations when, all too often, it was disease that was the main killer. Even sympathetic observers such as C. F. Andrews (1916) held women responsible for the moral decline on the plantations, labelling them 'rudderless vessels' with loose character.

New associations and relationships emerged during migration and indenture. None, perhaps, was symbolically more important than the institution of Jahajibhai, the brotherhood of the crossing forged out of need and necessity and a shared experience of making a traumatic voyage together. It was akin in many respects to real blood kinship. It persisted long after indenture ended as men travelled long distances to relive memories of their past. Jahajibhais did not intermarry among each other, just as brothers or cousins did not. The term Jahajibehan has come into vogue in some places, but this is a latter-day gender-driven invention. Indenture had enlarged the social space of women and gave them greater independence, but they for the most part remained in the domestic domain, without the freedom or the opportunity to travel long distances to relive their past with their fellow female travellers. Where it existed, it must have been ephemeral without the enduring power of Jahajibhai.

\section{CULTURE AND CHANGE}

About 85 per cent of the indentured migrants were Hindus and 15 per cent Muslim. All castes were represented in the indentured population in roughly the same proportion as their size in the population in rural India, comprising principally the middling agriculturalists and labouring classes. They brought with them the Indian peasant habits of thought and behaviour, food and fashion, religious traditions and rituals, and musical tastes. These, along with the religious texts, provided the migrants succour and sustenance in their daily lives largely taken up by mindless work. Many of these survived indentures to provide 
structure and coherence to the emerging Indian communities after indenture.

Indenture necessarily involved rupture and disruption. It could not be otherwise in a new homeland, in a new landscape requiring change and adaptation. Loss of cultural practices and language occurred more in some places than in others. Christianity achieved greater success in the Caribbean, for instance, thanks to the efforts of the Canadian Presbyterian Mission which went there in 1869 (Samaroo 1996; Jayawardena 1966), but it was rejected as the religion of the white officials and planters in others, such as Fiji. Indian religious practices may have frayed but they never disappeared. Rudimentary mosques appeared on many plantations and, whenever they could, believers travelled miles on foot for the Friday prayers. Similarly, Hindus observed their rituals and ceremonies both on the plantations and in make-shift huts (kutis) at designated places.

\section{RAMAYANA AND PANCHAYAT}

One text, above all, found particular favour among Hindus: the Ramayana of Goswami Tulsidas. The story of Rama's banishment was familiar to the indentured labourers who came from the region where the drama takes place. Written in accessible Avadhi, the text was comprehensible to the largely non-literate labourers. It was the story of a noble prince, heir to the throne of Ayodhya, who was banished into the forest so that his father, Dashrath, could keep his promise to one of Rama's stepmothers, Kaikeyi, who wanted her own son to be crowned king. Banished through no fault of his own, Rama did return triumphant after a 14-year exile. This rendition of Rama's tribulations resonated in the experience of the indentured labourers. They, too, had been forced to leave their homes through no fault of their own but they, too, would triumph in the end. The Ramayana provided a balm for the bruised soul of a displaced people. Read collectively to the accompaniment of elementary music (dholak, harmonium, dandtal), the Ramayana recital was a source of both enlightenment and entertainment. 
An institution that played an important role in regulating social relationships on the plantations and later was Panchayat, literally a fiveperson council of respected elders who adjudicated petty disputes involving sexual transgressions, work, breaches of privacy and pilfering. This was a time-tested practice in India with which people were familiar. Further, the protocols and practices of the courts (Kort Kachehri), conducted in English, were alien and forbidding, and expensive. Panchayats disappeared as the indentured labourers became more settled, as the community grew and diversified and as western ways of doing things began to intrude more into the daily lives of the people.

\section{THE END OF INDIAN INDENTURE}

By the second decade of the twentieth century, the heyday of Indian indenture was over; indentured emigration had either ended (to Natal in 1911) or severely reduced (Caribbean). By then, the scheme had become unfashionable. A more important reason for its unpopularity was the rising tide of Indian nationalism following Mahatma Gandhi's return from South Africa and his various campaigns for social improvement and national pride, such as the Champaran satyagraha. Indenture began to be seen as a blot on India's image as it was struggling for a rightful place among emerging nations of the world. It had to go and so it did. All indentured emigration ceased in 1917 and the indenture system itself was abolished on 1 January 1920, bringing to a close a remarkable episode in organised labour migration in modern times (Mahase 2020).

By the time indenture ended, the face of many a tropical colony had changed forever. Sugar cane, the slave crop, had been their lifeblood for a century or more. A bedraggled collection of men and women from different parts of the Indian subcontinent, from widely divergent social and economic backgrounds, had been transformed into a relatively coherent community, independent, egalitarian, pragmatic, resilient and self-reliant, with a melded culture and language. The children of the midnight of indenture were now looking forward to a new dawn. 


\section{HISTORIOGRAPHY}

For much of the nineteenth century, Indian indenture attracted little attention from the wider public beyond the occasional condemnation from humanitarian groups. By the end of the century, as consciousness of iniquities in the system grew and its glaring abuses began to come to light, criticism increased. The early writings, by missionaries and activists, were morally charged and highly censorious, with the indentured migrants themselves portrayed as a degraded people suffering at the hands of a heartless system (Burton 1910). After the end of indenture the focus shifted to their legal and political difficulties as residents in their new homelands and India's responsibilities towards its 'overseas Indian' citizens (Kondapi 1951). This ended with India's independence in 1947 and its preoccupation with a host of internal and external problems closer to home, and Jawaharlal Nehru's declaration at Bandung in 1954 that overseas Indians should associate themselves fully with the places of residence rather than looking to India for protection and guidance. This approach of active disengagement would continue well to the end of the twentieth century when India would once again discover the value of its new diaspora.

Among scholars, the first to study the evolution of Indian indentured communities were anthropologists, and the 1960s was their heyday (Kuper 1960; Benedict 1981; Mayer 1962; Niehoff and Niehoff 1960; Klass 1961; Jayawardena 1963). They produced finely grained ethnographic accounts dealing principally with questions of cultural change and cultural persistence, the transformation of social institutions and practices, family structures, and ways of celebrating life and mourning its passing. These accounts are still worth consulting for the special insights they provide into the evolution of the Indian indentured diaspora.

There were occasional decent historical accounts (Gillion 1962) but the truly captivating historical study of Indian indenture came in 1974 with the publication of Hugh Tinker's A New System of Slavery. In a single volume of persuasive prose, Tinker argued that, in all material respects, indenture was another form of slavery, 
replete with massive breaches of labour ordinances, fraudulence and violence in the recruitment of labourers and their supervision on the plantations, the ineffectuality of protective legislations and the degradation of the social and moral life of the workers: this and much more. Tinker's imaginative sympathy is admirable, but his dark picture admits of little change over time, of the agency of the labourers themselves in making their own history. And indenture did not last for a person's lifetime, as slavery did.

His book came out at a time when Indian communities all over the developing world were facing exclusion and discrimination, from the Black Power movement in Trinidad to Forbes Burnham's racist socialism in Guyana to the assertions of the Creole plantocracy in Mauritius. South Africa's apartheid regime was at its height and Fijian nationalists were agitating for the deportation of their Indian compatriots to India. At a time like this, a narrative emphasising suffering and servitude added strength to the call for equality and inclusion, that they had earned their right to full citizenship. For all its many internal flaws of argument and research, the book was for its time an important contribution.

The real advance towards a new indenture historiography came from the Caribbean around the same time as the publication of Tinker's book. It came from a conference on Colonialism and Identity in Trinidad at which V. S. Naipaul spoke. He bemoaned the absence of historical consciousness among his people and a written history that did not seem authentic (Brereton and Dookeran 1975). This was history close and personal that explored the link between the past and the present. Around the same time appeared John Gaffar La Guerre's edited book From Calcutta to Caroni, in which scholars, most descended from indenture, explored the lived experience of indenture. The gaze had shifted from the corridors of power in Whitehall to the cane fields of Caroni and the Booker Estates, from the concerns of the sahibs to the life of the subalterns on the plantations. This was history from within, engaged, that went close to how people saw themselves in the larger scheme of things. And this, 
more or less, has remained the focus of much research on Indian indenture done by its descendants.

The Caribbean example was followed independently elsewhere. My own work on the social background of Fiji's Indian migrants, on women, suicide and resistance on plantations, moved beyond an examination of policy and legislation to focus on the actual experience of the labourers suggested new themes and approaches (Lal 2010 reprints many papers written in the 1980s). A similar exercise was under way in South Africa under the leadership of Surendra Bhana (among other books Bhana 1991; Bhana and Brain 1990). Inspirational leadership of scholars like Bhana in South Africa and Brinsley Samaroo in Trinidad produced a younger generation of scholars who would go on to make their own distinctive contributions to the field (see Lal 2021). The founding of regional universities encouraged research and publications on indenture. Three universities which played a seminal role were the University of Durban-Westville (1961), University of the West Indies in Trinidad (1950) and the University of the South Pacific in Fiji (1968). They continue to play an important role in fostering research on indenture in their respective countries.

Interest in the experience of Indian indenture has revived in recent decades for a variety of reasons. The 'roots industry' is one of them as descendants of indenture, including those living in the West, seek to understand their history and heritage. The Government of India itself has fostered an interest in the subject. The prominence of people from the indentured diaspora in international sports, politics and administration, literature and jurisprudence has aroused curiosity in their background. Individual scholars in North America, Europe and the United Kingdom have made important contributions to the field. In India, too, there are several research centres and individual scholars who have raised its profile as part of fields of research including gender, folk culture, protest and resistance, and subaltern and Indian nationalist history. ${ }^{5}$

The study is also moving beyond normative description and analysis. The Indo-Mauritian poet and semiologist Khal Torabally has 
coined the term 'coolitude' and edited a collection of essays on the subject with historian Marina Carter (Carter and Torabally 2002). The term encapsulates both an interpretation and an artistic immersion in the world of the 'coolie'. It seeks to understand migration and indenture across the globe as a transcultural process in non-essentialist ways through poetry, art and prose, both conventional and experimental. In a recent book, which I edited, Girmitiyas: Making of their Memory Keepers (2021), scholars of Indian indenture from the indentured diaspora reflect in deeply personal ways their journeys to the subject and on the challenges as well as the satisfactions of writing about a subject of which they themselves are a part. History and autobiography mingle to suggest more personal ways of writing and interpreting historical experiences. In this sense, it joins the genre of introspective history now becoming increasingly common (e.g. Boles 2004; Munro and Reid 2017). In 2018, David Dabydeen, Maria del Pilar Kaladeen and Tina Ramnarine published an anthology of writings, We Mark Your Memory, by descendants of indenture, to mark the end of indentured emigration. ${ }^{6}$ Essays and poems in it portray the meaning and legacy of the indenture experience as filtered through the literary imagination. Travelogues and search for roots (Gaiutra Bahadur's Coolie Woman being an outstanding example) have also produced works that go beyond the traditional boundaries of scholarship (Mohan 2013; Bahadur 2013; Gubili 2018; Bismillah 2016). In these accounts, the personal and the professional mingle easily to create a body of work that is at once authentic and compelling. The story of indenture will continue to be told in a variety of genres.

We live in an age when words are not the only carriers of knowledge and information. The advent of the internet has revolutionised our way of knowing about the past. Increasingly, blogs, websites, documentaries and videos, of varying quality and accuracy, are teaching a larger audience growing up in the world of the web. This medium has its obvious advantage visually as it humanises the story, but it also means that context, nuance and subtlety miss out in favour of a dramatic story. Some tend to reduce a complex history to an ideology of grief and 
grievance for particular purposes, such as seeking reparation from colonial powers that used indentured labour. Some insist on a 'correct history of indenture' whatever that may look like. These history wars will continue. One hopes that history will not become a branch of heritage study, a subject for veneration and worship, lived experience in funny costume, but will remain within the realm of reasoned discourse and debate that will do justice to a complex human experience. The girmitiyas deserve that at the very least.

\section{NOTES}

1 I thank David Dabydeen for the invitation to write this paper and Doug Munro for reading an early draft of it.

2 In the case of Trinidad and Fiji, for instance, the sugar industry is in the doldrums, with cane farms abandoned and milling infrastructure in decay.

3 The literature is vast but see among many others, Carter 1994; Lal 1985; Pande 2020; Goundar et al. 2021.

4 See Lal 2010. For a comprehensive list of studies of indentured women's experiences, by dozens of scholars, many women, see the Bibliography section of the Ameena Gafoor Institute website, ameenagafoorinstitute.org

5 There are several centres for the study of Indian diaspora in India, dealing partially with the indenture experience. Among many scholars with serious commitment to the history of Indian migrants are Ashutosh Kumar of Banaras Hindu University and Amit Mishra of Ashoka University. Several early career researchers are working on literary and gender issues.

$6 \quad$ An earlier such compilation was Macdonald 1998.

\section{REFERENCES}

Andrews, C. F. 1916. Indentured Labour in Fiji: An Independent Report (Calcutta: privately published).

Bahadur, Gaiutra. 2013. Coolie Woman (London: Hurst \& Co.).

Benedict, Burton. 1981. Indians in a Plural Society: Report on Mauritius (London: Her Majesty's Stationary Office). 
Bhana, Surendra. 1991. Indentured Indian Emigrants to Natal, 1860-1902 (Delhi: Promilla \& Co.).

Bhana, Surendra, and Joy Brain. 1990. Setting Down Roots: Indian Migrants in South Africa, 1860-1911 (Cape Town: Witwatersrand University Press).

Bismillah, Vicki. 2016. Indentured: A Labourer's Journey (Toronto: Tamarind Tree).

Boles, John T. (ed.). 2004. Shapers of Southern History (London: University of Georgia Press).

Brereton, Bridget, and Winston Dookeran (eds). 1975. East Indians in the Caribbean: Colonialism and the Struggle for Identity (St Augustine: University of the West Indies Press).

Burton, J. W. 1910. Fiji of Today (London: Charles Kelly).

Carter, Marina. 1994. Lakshmi's Legacy: The Testimonies of Indian Women in 19th Century Mauritius (Port Louis: Editions de l'Ocean Indien).

Carter, Marina, and Khal Torabally. 2002. Coolitude: An Anthology of the Indian Labour Diaspora (London: Anthem Southeast Asian Studies).

Dabydeen, David, Maria del Pilar Kaladeen and Tina Ramnarine. 2018. We Mark Your Memory (London: University of London Press).

Gillion, K. L. 1962. Fiji's Indian Migrants: A History to the End of Indenture in 1920 (Melbourne: Oxford University Press).

Goundar, Farzana, et al. (eds). 2021. Women, Gender and the Legacy of Slavery and Indenture (London: Routledge).

Gubili, Krishna. 2018. Viriah (Chennai: Notion Press).

Jayawardena, Chandra. 1963. Conflict and Solidarity on a Guyanese Plantation (London: Athlone Press).

Jayawardena, Chandra. 1966. 'Religious Belief and Social Change: Aspects of the Development of Hinduism', Comparative Studies in Society and History, 8(2): 211-40.

Klass, Morton. 1961. East Indians in Trinidad (New York: Columbia University Press).

Kondapi, C. 1951. Indians Overseas, 1838-1950 (New Delhi: Oxford University Press).

Kuper, Hilda. 1960. Indian People in Natal (Cape Town: University of Natal Press).

La Guerre, John Gaffar. 1974. From Calcutta to Caroni (St Augustine: University of the West Indies Press).

Lal, Brij V. 1983. Girmitiyas: Origins of the Fiji Indians (Canberra: Journal of Pacific History Monograph).

Lal, Brij V. 1985. 'Kunti's Cry: Women on Fiji Plantations', Indian Economic and Social History Review, 22: 55-71. 
Lal, Brij V. 2010. Chalo Jahaji: On a Journey of Indenture in Fiji (Canberra: ANU).

Lal, Brij V. (ed.). 2021. Girmitiyas: Making of their Memory Keepers (New Delhi: Primus Books).

Macdonald, Ian (ed.). 1998. They Came in Ships: An Anthology of IndoGuyanese Prose and Poetry (Leeds: People Tree Press).

Mahase, Radica. 2020. Why Should We Be Called Coolies? The End of Indian Indentured Labour (New Delhi: Manohar).

Mayer, Adrian. 1962. Peasants in the Pacific: A Study of Indian Rural Society in Fiji (London: Routledge \& Kegan Paul).

Mohan, Peggy. 2013. Jahajin (New Delhi: Harper Collins).

Munro, Doug, and John G. Reid (eds). 2017. Clio's Lives: Biographies and Autobiographies of Historians (Canberra: ANU Press).

Niehoff, Arthur and Juanita. 1960. East Indians in the West Indies (Milwaukee: Public Museum).

Pande, Amba (ed.). 2020. Indentured and Post-Indentured Women in the Indian Diaspora (New Delhi: Springer).

Samaroo, Brinsley. 1996. Pioneer Presbyterian: The Origin of Presbyterian Work in Trinidad (St Augustine: University of West Indies).

Tinker, Hugh. 1974. A New System of Slavery (Oxford: Oxford University Press). 